\title{
The Role of Cell-Free Fetal DNA as a Preventative Attempt to Decrease the Severity of Genetic Disorders: A Review
}

\author{
Agung Sosiawan ${ }^{1}$, Mala Kurniati ${ }^{2,3}$, RM Coen Pramono $\mathrm{D}^{4}$, \\ Indra Mulyawan ${ }^{5}$, Abdul Hadi Furqoni ${ }^{6}$, Indah Nuraini ${ }^{6}$, Qurrota A'yun ${ }^{6}$ \\ ${ }^{1}$ Senior Lecterur, Department of Dental Public Health, Faculty of Dental Medicine, Universitas Airlangga, \\ Surabaya, Indonesia, ${ }^{2}$ Post Graduate Doctoral Program, Faculty of Medicine, Universitas Airlangga, Surabaya- \\ Indonesia, ${ }^{3}$ Lecterur, Department of Biology, Faculty of Medicine, Universitas Malahayati, Lampung, Indonesia, \\ ${ }^{4}$ Professor, Department of Oral \& Maxillofacial Surgery, Faculty of Dental Medicine, Universitas Airlangga, \\ Surabaya, Indonesia, ${ }^{5}$ Lecterur, Department of Oral \& Maxillofacial Surgery, Faculty of Dental Medicine, \\ Universitas Airlangga, Surabaya, Indonesia, ${ }^{6}$ Researcher, Human Genetic and Forensic Laboratory, Institute of \\ Tropical Disease, Airlangga University, Surabaya, Indonesia
}

\begin{abstract}
The development of prenatal diagnosis has developed very rapidly over decades. Prenatal screening is applied to a mother with high-risk pregnancy (threatening the life of the fetus), such as a too-old mother or a too-young mother and having a certain disease in her medical history. Up until now, the curative method to treat genetic disorder is still developed and perfected. Therefore, a preventative action during pregnancy is important to do, such as Noninvasive Prenatal Testing (NIPT). NIPT method that is widely developed is the circulating cell-free fetal DNA (cffDNA) testing that can be useful for determining the fetal gender, the identification of specific single-gene disorders, blood type, paternity determination, and the potency of regular use for testing chromosomal abnormalities. The detection of cell-free fetal DNA in the maternal blood circulation provides a new expectation for NIPT, especially preventing the severity of genetic disorders.
\end{abstract}

Keywords: Cell-free fetal DNA, Prenatal diagnosis, Genetic disorder.

\section{Introduction}

The development of prenatal diagnosis has developed very rapidly over decades. Firstly, amniocentesis was developed at the beginning of 1970 and chorionic villus sampling (CVS) was developed at the beginning of $1980 .^{1,2,3}$ Invasive prenatal diagnosis (CVS and amniocentesis) is not a low-risk option for all mothers, because there are many limitations that need to be improved. The invention of cell-free DNA (cf DNA) began from a study conducted by Mandel and Metals

\section{Corresponding Author:}

\section{Dr. Agung Sosiawan, drg., M.Kes}

Senior Lecterur, Department of Dental Public Health, Faculty of Dental Medicine, Universitas Airlangga. Jl. Mayjen Prof. Dr. Moestopo No.47, Pacar Kembang, Surabaya City, East Jawa, Indonesia 60132 e-mail: agung-s@fkg.unair.ac.id in 1948 showing the availability of nucleic acid (DNA) circulating in the peripheral blood. ${ }^{4}$ Furthermore, a further study was conducted by Bianchi et al., in 1997 to identify fetal cells in maternal blood report the method to isolating the cells. ${ }^{5}$ Dennis Lo, in his research findings, also reported the existence of cell-free fetal DNA (cffDNA) circulation in the plasma of pregnant women. These findings paved the way for developing Noninvasive Prenatal Testing (NIPT). The discovery of cell-free fetal DNA in maternal plasma in 1997 triggered the scientists to develop a reliable method, namely noninvasive prenatal diagnosis.

Cell-Free Fetal (cff) during Pregnancy: In 1953, Peter Brian Medawar, in his publication, explained the immunological tolerance during pregnancy. Peter suggested that there was anatomy that became a barrier between a mother and the fetus. For his finding, he was awarded a Nobel prize in $1960 .{ }^{1}$ However, as time went by, his finding was proven wrong. During pregnancy, 
fetal cells flow across the placenta to the maternal circulation and vice versa, and the fetal cells can be identified as stem cells. ${ }^{7}$ Cell free fetal (cff) DNA is from trophoblast cells. Hence, the fragment of fetal DNA is released to the maternal circulation after the degradation of trophoblasts, the apoptotic fetal cells circulating in maternal blood can be the minor source of cffDNA. ${ }^{8,9}$ In the maternal blood circulation during early and late pregnancy, there are around 3 to $6 \%$ of the total cffDNA. ${ }^{6}$

In the current development by using microfluidic digital polymerase chain reaction (PCR), it shows a higher concentration of fetal DNA than expected of around 10 to $12 \%$ from the total DNA in the maternal plasma. ${ }^{10}$ The size of circulating cffDNA mostly in the form of a short fragment of DNA; its length is around 193 bp (base pair) and it can be detected since week 4 of pregnancy, even though it can be definitely known since week 7 of pregnancy, and the concentration is significantly increased during the last 8 weeks of pregnancy. The half-life of cffDNA is around 16 minutes and is undetectable 2 hours after giving birth. ${ }^{6,11,12,13}$

The Potency of Genetic Materials in Maternal Plasma as Biomarkers for Fetal Abnormalities: A study on genetic materials in maternal plasma during pregnancy as biomarkers had a special challenge. It is due to a high number of fetal components that can pass through the placenta or are directly released from the placenta, and it is important to note that the fetal components can be isolated and distinguished according to maternal biofluids. ${ }^{14}$ The followings are the components of maternal plasma that potentially become the biomarkers of fetal abnormalities:

(1) Protein: Human plasma proteome is an invaluable resource to assess health status and since it reflects the physiological status of an individual. ${ }^{14}$ Protein as biomarkers in prenatal diagnosis for congenital malformation has not been widely investigated and understood. Clinically, the application of maternal plasma proteins is an analysis of alpha-fetoprotein (AFP) analysis for neural tube defects (NTD). ${ }^{15}$

(2) Micro RNA: MicroRNA (miR) is a series of short RNAs with a length of around 22 nucleotides and it is functional for gene expression. ${ }^{16,17} \mathrm{~A}$ unique microRNA profile can also be used as biomarkers for congenital malformation. Congenital diseases like congenital diaphragmatic hernia $(\mathrm{CDH})$ and congenital heart disease (CHD) can be associated with the failure of miR gene expression. ${ }^{18,19,20,21}$
In the development, the miR profile, besides being a new diagnostic instrument in certain diseases, potentially can be biomarkers for fetal health.

(3) Long Non-Coding RNAs: Long RNA noncoding (lncRNA) is a DNA transcription with a length of more than $\sim 200$ nucleotides and has no protein code. $\mathrm{Gu}$ et al., identified five lncRNAs (ENST00000436681, ENST00000422826, AA584040, AA709223, dan BX478947) from maternal plasma to detect fetal congenital heart disease. LncRNA has a big potency as prenatal biomarkers yet it still needs further investigation. ${ }^{22}$

(4) Circular RNAs: Circular RNAs (CircRNA) are circular RNA particles resulted from the ligation of pre-mRNA ('back-splicing'). CircRNA has a circular structure and remarkably high stability in biological matrices, such as plasma and saliva. A study by Peng et al., showed that circ-ZNF609 was detected in the tissue of a patient with Hirschsprung (HD) disease. Since the stability of circRNA is high and it plays a role in cell differentiation, it fulfills the requirements as biomarkers for fetal abnormalities. ${ }^{23,24}$

(5) Circulating Fetal DNA: Circulating Fetal DNA(cfDNA) is produced from the placenta to maternal circulation during pregnancy; cfDNA is from cytotrophoblast and apoptosis in the syncytiotrophoblast or syncytiotrophoblast fusion in the physiological condition. cfDNA as biomarkers can provide information to patients for medical decision-making without increasing the risk of pregnancy loss and providing additional diagnostic information, treatment planning, the strategy, and the management of counseling. ${ }^{25}$

The Detection and the Clinical Application of eff DNA: Isolating cffDNA is a special challenge. Several problems generally encountered when detecting cffDNA in maternal circulation: (1) the concentration of cffDNA in the blood is relatively low; (2) the total cff DNA is varied among individuals; (3) the cffDNA molecules are less than the total of maternal DNA with a ratio of $20: 1$; (4) the fetus inherits half of the maternal genome. ${ }^{26}$ The new generation of NIPT technology emphasizes the cffDNA testing during the first trimester using two method. First, the use of next-generation sequencing (NGS) or known as MPSS (Massively Parallel Shotgun Sequencing). MPSS is a sophisticated and unique technology with a less amount of DNA sequence. The second method is 
using the target sequence; this method uses a different fraction of coding sequence and is detected in all chromosomes, however, the target sequence amplifies either non-polymorphic or polymorphic regions. ${ }^{1,27}$ The NIPT method refers to circulating cffDNA testing and it can be used for fetal gender, the identification of specific single-gene disorders, blood type, paternity determination, and the potency of routine use for testing Down Syndrome (DS) in all pregnancies. ${ }^{8}$ Several latest studies showed that the screening method is the most effective way for trisomy 21 , with a detection level of more than $99 \%$ and a false positive rate of around $0.1 \%$, coming from cffDNA testing. ${ }^{2}$

\section{Conclusion}

Non-Invasive Prenatal can be used as an initial health screening test and enhanced by fetal examination to see abnormalities either through diagnostic tools or maternal serum biomarkers. One such serum biomarker is using cffDNA for fetal and genetic diagnosis the chromosomal conditions of this examination have a major influence on the development of fetal medicine practice around the world.

Ethical Clearance: This study was approved by the ethical committee of the Faculty of Dentistry, Universitas Airlangga, 156/HRECC.FODM/III/2020.

Conflict of Interest: There was no conflict of interests regarding the publication of this study.

Source of Funding: The funding source of this study was supported by Directorate of Research and Community Services, Deputy of Research and Development Reinforcement, Ministry of Research and Technology/National Agency for Research and Innovation.

\section{References}

1. Norwitz, ER; Levy B. Noninvasive Prenatal Testing : The Future Is Now. Rev Obstet Gynecol. 2013;6(2):48-62.

2. Leon SA, Shapiro B, Sklaroff DM, Yaros MJ. Free DNA in the Serum of Cancer Patients and the Effect of Therapy. Cancer Res. 1977;37(3):646-50.

3. Bianchi DW. Fetal cells in the maternal circulation: Feasibility for prenatal diagnosis. Br J Haematol. 1999;105(3):574-83.

4. Suraj S, Dhar C, Srivastava S. Circulating nucleic acids: An analysis of their occurrence in malignancies (review). Biomed Reports. 2017;6(1):8-14.

5. Bianchi DW, Williams JM, Sullivan LM, Hanson FW, Klinger KW, Shuber AP. PCR quantitation of fetal cells in maternal blood in normal and aneuploid pregnancies. Am J Hum Genet. 1997;61(4):822-9.

6. Lo YMD, Tein MSC, Lau TK, Haines CJ, Leung TN, Poon PMK, et al. Quantitative analysis of fetal DNA in maternal plasma and serum: Implications for noninvasive prenatal diagnosis. Am J Hum Genet. 1998;62(4):768-75.

7. Desai, G R, Creger, P W. Maternofetal Passage of Leukocytes and Platelets in Man. Blood. 1963;21(6):665-73.

8. Ghorbian S. Applications of cell-free fetal DNA in maternal serum. Int $\mathrm{J}$ Infertil Fetal Med. 2012;3(2):33-9.

9. Sekizawa A, Yokokawa K, Sugito Y, Iwasaki M, Yukimoto Y, Ichizuka K, et al. Evaluation of bidirectional transfer of plasma DNA through placenta. Hum Genet. 2003;113(4):307-10.

10. Lun FMF, Chiu RWK, Chan KCA, Tak YL, Tze KL, Lo YMD. Microfluidics digital PCR reveals a higher than expected fraction of fetal DNA in maternal plasma. Clin Chem. 2008;54(10):166472.

11. Chan KCA, Zhang J, Hui ABY, Wong N, Lau TK, Leung TN, et al. Size Distributions of Maternal and Fetal DNA in Maternal Plasma. Clin Chem. 2004;50(1):88-92.

12. Birch L, English CA, O’Donoghue K, Barigye O, Fisk NM, Keer JT. Accurate and robust quantification of circulating fetal and total DNA in maternal plasma from 5 to 41 weeks of gestation. Clin Chem. 2005;51(2):312-20.

13. Lo YMD, Leung TN, Tein MSC, Sargent IL, Zhang J, Lau TK, et al. Quantitative abnormalities of fetal DNA in maternal serum in preeclampsia. Clin Chem. 1999;45(2):184-8.

14. Wagner R, Tse WH, Gosemann JH, Lacher M, Keijzer R. Prenatal maternal biomarkers for the early diagnosis of congenital malformations: A review. Pediatr Res [Internet]. 2019;86(5):560-6. Available from: http://dx.doi.org/10.1038/s41390019-0429-1

15. An D, Wei X, Li H, Gu H, Huang T, Zhao G, et al. Identification of PCSK9 as a novel serum biomarker for the prenatal diagnosis of neural tube 
defects using iTRAQ quantitative proteomics. Sci Rep. 2015;5(June):1-11.

16. Bartel DP. MicroRNAs: Target Recognition and Regulatory Functions. Cell. 2009;136(2):215-33.

17. Sayed D, Abdellatif M. Micrornas in development and disease. Physiol Rev. 2011;91(3):827-87.

18. Sessa R, Hata A. Role of microRNAs in lung development and pulmonary diseases. Pulm Circ. 2013;3(2):315-28.

19. Xie W. Circulating microRNAs as potential biomarkers for diagnosis of congenital heart defects. World J Emerg Med. 2016;7(2):85.

20. Li X, Zhao Z. MicroRNA biomarkers for early detection of embryonic malformations in pregnancy. Physiol Behav. 2019;176(3):139-48.

21. Song Y, Higgins H, Guo J, Harrison K, Schultz EN, Hales BJ, et al. Clinical significance of circulating microRNAs as markers in detecting and predicting congenital heart defects in children. J Transl Med [Internet]. 2018;16(1):1-11. Available from: https://doi.org/10.1186/s12967-018-1411-0

22. Gu M, Zheng A, Tu W, Zhao J, Li L, Li M, et al. Circulating LncRNAs as novel, non-invasive biomarkers for prenatal detection of fetal congenital heart defects. Cell Physiol Biochem. 2016;38(4):1459-71.
23. Lasda E, Parker R. Circular RNAs: Diversity of form and function. Rna J. 2014;20(12):1829-42.

24. Peng L, Chen G, Zhu Z, Shen Z, Du C, Zang R, et al. Circular RNA ZNF609 functions as a competitive endogenous RNA to regulate AKT3 expression by sponging miR-150-5p in Hirschsprung's disease. Oncotarget. 2017;8(1):808-18.

25. Taglauer ES, L. Wilkins-Haug, D.W. Bianchi. Review: Cell-free fetal DNA in the maternal circulation as an indication of placental health and disease. Placenta. 2014;35(5):1-13.

26. Wright CF, Burton $H$. The use of cell-free fetal nucleic acids in maternal blood for noninvasive prenatal diagnosis. Hum Reprod Update. 2009;15(1):139-51.

27. Heft H, Soulodre C, Cowan K, Laing A, Kaulback K, Mcdowell S, et al. Noninvasive Prenatal Testing for Trisomies 21, 18, and 13, Sex Chromosome Aneuploidies, and Microdeletions: A Health Technology Assessment. Ont Health Technol Assess Ser [Internet]. 2019;19(4):1-166. Available from: http://www.hqontario.ca/evidence-toimprove-care/journal-ontario-health-technologyassessment-series 